\title{
IDENTIFIKASI CITRA DAGING AYAM BERFORMALIN MENGGUNAKAN METODE FITUR TEKSTUR DAN K-NEAREST NEIGHBOR (K-NN)
}

\author{
Faris Mushlihul Amin \\ Universitas Islam Negeri Sunan Ampel Surabaya ${ }^{1}$, faris@ uinsby.ac.id \\ DOI: https://doi.org/10.15642/mantik.2018.4.1.68-74
}

\begin{abstract}
Abstrak
Penelitian bertujuan untuk membuat sistem identifikasi daging ayam segar untuk mendeteksi perbedaan antara daging ayam berformalin dan tidak berformalin berdasarkan citra daging ayam mentah. Metode ekstraksi ciri yang digunakan adalah metode Fitur Tekstur yang termasuk dalam metode statistik dimana dalam perhitungan statistiknya menggunakan distribusi derajat keabuan (histogram) dengan mengukur tingkat kekontrasan, granularitas, dan kekasaran suatu daerah dari hubungan ketetanggaan antar piksel di dalam citra kemudian dilakukan ekstraksi fitur, hasil ekstraksi fitur kemudian diklasifikasikan oleh K-NN. Dengan klasifikasi menggunakan K-NN diperoleh hasil akurasi klasifikasi yang tinggi. Metode K-NN merupakan metode yang sangat baik dalam menangani masalah pengenalan pola-pola komplek dalam bentuk pelatihan data dan kalibrasi pengolahan, berdasarkan literatur metode yang sangat cepat dan tinggi akurat lebih dari metode lain. Gambar pengamatan akan dilakukan pada beragam jarak antara kamera smartphone dan sampel daging ayam.
\end{abstract}

Kata kunci: Ayam, Fitur Tekstur, K-NN

\begin{abstract}
The research aimed to create a fresh chicken meat identification system to detect differences between formalin and non-formalin chicken meat based on the image of raw chicken meat. Feature extraction method used is the Feature Texture method which is included in the statistical method where the statistical calculation uses a gray degree distribution (histogram) by measuring the level of contrast, granularity, and roughness of an area from the neighboring relationships between pixels in the image then feature extraction, results feature extraction is then classified by K-NN. With the classification using K-NN results obtained high classification accuracy. The K-NN method is a very good method of dealing with the problem of recognizing complex patterns in the form of data training and processing calibration, based on very fast and high accurate literature methods more than other methods. Observation images will be carried out at various distances between the smartphone camera and chicken meat samples.
\end{abstract}

Keywords: Chicken, Texture Feature, K-NN

\section{Pendahuluan}

Ayam adalah hewan unggas yang paling umum di seluruh dunia, dan telah diternakkan dan dikonsumsi sudah selama ribuan tahun lalu. Manfaat makan daging ayam bagi kesehatan jelas sangat tinggi,karena daging ayam mengandung protein tinggi. Tingginya kebutuhan masyarakat akan daging ayam setiap harinya menyebabkan banyak para pedagang daging ayam mencoba mengoplos daging segar dengan daging yang sudah rusak untuk memperoleh keuntungan yang lebih besar walaupun dengan cara yang tidak dibenarkan atau tidak halal, hal ini tentu sangat merugikan konsumen. Kebanyakan masyarakat awam terutama ibu-ibu rumah tangga tidak mengetahui daging ayam mentah yang telah terkontaminasi formalin dan daging ayam mentah yang 
tidak mengandung formalin sehingga setelah dikonsumsi akan mengakibatkan penyakit yang dapat menyebabkan kematian.

Selama ini untuk mengetahui sebuah produk makanan mengandung zat kimia berbahaya atau tidaknya seperti formalin, hanya dilakukan dengan pengujian di laboratorium kimia. Sampel produk makanan yang diduga mengandung zat kimia berbahaya seperti formalin akan dibawa ke laboratorium terlebih dahulu Karena proses pengujiannya tidak dapat dilakukan di tempat produk makanan itu diproduksi atau dipasarkan. Sehingga hasil dari pengujian sampel makanan tersebut tidak dapat kita ketahui secara cepat, karena harus menunggu hasil yang dikeluarkan oleh petugas laboratorium kimia. Penelitian untuk membuktikan produk makanan yang berformalin maupun tidak berformalin telah dilakukan dengan berbagai objek dan metode. Metode pendeteksian yang banyak digunakan adalah metode pengolahan citra dan metode jaringan saraf tiruan, dari metode tersebut dapat diketahui nilai acuan untuk mengetahui makanan tersebut mengandung formalin atau tidak formalin. Untuk mengenali obyek dalam citra dibutuhkan parameter parameter yang mencirikan obyek tersebut. Ciri yang dapat digunakan untuk membedakan obyek satu dengan obyek lainnya di antaranya adalah ciri bentuk, ciri ukuran, ciri geometri, ciri tekstur, dan ciri warna.

Tujuan yang ingin dicapai dalam penelitian ini adalah untuk membangun aplikasi berbasis matlab yang dapat membedakan antara daging ayam berformalin dan tidak berformalin dengan menerapkan metode Fitur Tekstur dan K-NN menggunakan Matlab r2014a. Adapun manfaat yang ingin didapatkan dari penelitian ini adalah hasil penelitian ini diharapkan dapat memberikan kontribusi dan masukan bagi siapa saja yang membutuhkan informasi yang berhubungan dengan judul penelitian ini.Dan mengetahui bagaimana proses penerapan pengolahan citra digital dan metode Fitur Tekstur dan K-NN, serta membantu masyarakat atau para konsumen untuk dapat membedakan daging ayam berformalin atau tidak mengandung formalin.

\section{Tinjauan Pustaka}

\subsection{Penelitian Terdahulu}

Penelitian sejenis ini sebelumnya pernah dilakukan oleh beberapa peneliti sebagai berikut :

Penelitian yang dilakukan oleh Arie Qur'ania dkk yang berjudul Analisis Tekstur Dan Ekstraksi Fitur Warna Untuk Klasifikasi Apel Berbasis Citra betujuan untuk mengklasifikasi jenis apel. Metode yang digukan dalam penelitian tersebut yakni K-Nearest Neighbor (K-NN) dengan nilai parameter $\mathrm{K}$ yang digunakan yakni $\mathrm{k}=1$ sampai $\mathrm{k}=3$. ekstraksi fitur yang digunakan yakni fitur tekstur dan fitur warna RGB(red, green, dan blue). Hasil penelitian menunjukkan tingkat akurasi sebesar 93,33\% untuk fitur homogenitas, 73,33\% untuk fitur tekstur dan $100 \%$ untuk fitur RGB[1].

Penelitian selanjutnya dilakuan oleh Retno Nugroho Whidhiasih dkk, dalam penelitiannya yang berjudul Klasifikasi Buah Belimbing Berdasarkan Citra RedGreen-Blue Menggunakan Knn Dan Lda. Penelitian tersebut membandingkan metode klasifikasi K-nearest neigbourhood (KNN) dan Linear Discriminant Analysis (LDA) dengan variabel R-G dan R-G-B dari citra buah belimbing untuk memprediksi tingkat kemanisan buah belimbing[2]

Penelitian serupa dilakukan oleh Oky Dwi Nurhayati dalam penelitiannya yakni Sistem Analisis Tekstur Secara Statistik Orde Pertama Untuk Mengenali Jenis Telur Ayam Biasa Dan Telur Ayam Omega-3. Metode pengolahan citra yang digunakan pada penelitian tersebut meliputi pengubahan nilai keabuan, peningkatan kontrast citra, penapisan dengan menggunakan filter gaussian, ekualisasi histogram, segmentasi thresholding, dan klasifikasi dengan pendekatan statistik orde pertama dapat 
digunakan sebagai sarana analisis untuk membedakan jenis telur ayam omega-3 maupun telur ayam biasa[3]. Sedangkan menurut Yufika Agustyani, Sri Setyaningsih, Arie Qur'ania(2014) dalam penelitiannya Model Deteksi Kandungan Formalin Pada Ikan Dengan Citra (HSV) Menggunakan K-Nearest Neighbor mengatakan Identifikasi ikan yang mengandung formalin. Tujuan dari penelitian ini adalah merancang dan membangun model yang mampu mendeteksi kandungan formalin pada ikan melalui citra ikan tersebut[1]

\subsection{Landasan Teori}

\section{Ayam}

Ayam merupakan salah satu ternak unggas yang sudah tidak asing lagi dikalangan masyarakat. Ayam yang digunakan oleh masyarakat untuk diolah biasanya adalah ayam potong, untuk memilih daging ayam segar yang biasa perlu diperhatikan beberapa hal, yaitu warna daging yang putih kekuningan, warna lemak yang putih kekuningan dan merata di bawah kulit, memiliki bau yang segar, kekenyalan yang elastis dan tidak ada tanda-tanda memar atau tanda lain yang mencurigakan. Daging ayam termasuk mengandung gizi yang tinggi, selain dari proteinnya juga daging ayam mengandung lemak. Protein pada ayam yaitu 18,2g sedangkan lemaknya berkisar 25,0 g.

\section{Formalin}

Formalin adalah salah satu zat kimia yang berbahaya, yang penggunaan dilarang oleh Pemerintah. Di dalam formalin biasanya ditambahkan metanol hingga $15 \%$ sebagai pengawet. Dan atas dasar inilah formalin digunakan sebagai pengawet bahan makanan, baik dalam bentuk olahan ataupun segar seperti daging ayam yang masih segar. Selain itu formalin juga dikenal sebagai bahan pembunuh hama dan banyak digunakan dalam industri. Penggunaan formalin untuk mengawetkan makanan sesungguhnya telah dilarang sejak tahun 1982. Pemerintah juga telah mengeluarkan dua peraturan untuk mengatur penggunaan bahan kimia ini. Yaitu Peraturan Menteri Kesehatan Nomor 472 Tahun 1996 tentang Pengamanan Bahan Berbahaya bagi Kesehatan, dan Keputu-san Menteri Perindustrian dan Perdagangan Nomor 254 Tahun2000 tentang Tata Niaga Impor dan Peredaran Bahan Berbahaya Tertentu. Formalin dan rodamin termasuk dalam kategori bahan berbahaya tersebut yang tenggunaan-nya harus diawasi secara ketat.

\subsection{Teori Dasar 1.Citra}

Citra (image) adalah gambar pada bidang dwimatra (dua dimensi). Ditinjau dari sudut pandang matematis, citra merupakan fungsi menerus (continue) dari intensitas cahaya pada bidang dwimatra. Citra sebagai keluaran dari suatu sistem perekaman data dapat bersifat optik berupa foto, analog berupa sinyal video seperti gambar pada monitor televisi dan digital yang dapat langsung disimpan pada suatu pita magnetik.

\section{Pengolahan Citra}

Pengolahan citra merupakan kegiatan memperbaiki kualitas citra agar mudah di interpretasi oleh manusia / mesin (komputer). Inputannya adalah citra dan lebih baik daripada citra masukan $\rightarrow$ misal citra warnanya kurang tajam, kabur (blurring), mengandung noise (misal bintik-bintik putih), dll sehingga perlu ada pemrosesan untuk memperbaiki citra karena citra tersebut menjadi sulit diinterpretasikan karena informasi yang disampaikan menjadi berkurang.

\section{Ekstrasi Ciri}

Ekstraksi Ciri Statistik Analisa tekstur lazim dimanfaatkan sebagai proses antara untuk melakukan klasifikasi dan interpretasi citra. Suatu proses klasifikasi citra berbasis analisis tekstur pada umum -nya membutuhkan ekstraksi ciri, yang dapat terbagi dalam empat macam metode yaitu: statistical, geometri, model-based, dan signal processing[4]. 


\section{Ekstraksi Ciri Fitur Tekstur}

Ekstraksi Ciri Tekstur Analisa tekstur lazim dimanfaatkan sebagai proses antara untuk melakukan klasifikasi dan interpretasi citra. Suatu proses klasifikasi citra berbasis analisis tekstur pada umumnya membutuhkan ekstraksi ciri, yang dapat terbagi dalam empat macam metode yaitu:

1. Geometri

Metode ini digunakan untuk mendeskripsikan atau mejelaskan elemen-elemen tekstur dan penempatan kaidah untuk menjelaskan organisasi spasisal diantara elemen-elemen.

2. Model-based

Metode ini biasanya berdasarkan pada sebuah gambar dari sebuah model gambar. Base model dapat digunakan untuk menjelaskan dan menkombinasikan tekstur.

\section{Signal Processing}

Metode ini berdasarkan pada analisis frekuensi pada sebuah gambar.Ektraksi ciri dapat diilustrasikan ke dalam dua bentuk yaitu histogram citra dan matrik.

\section{Fitur Tekstur Statistik}

Fitur pertama yang dihitung secara statistis adalah rerata intensitas. Komponen fitur ini dihitung berdasar persamaan

$$
\boldsymbol{m}=\sum_{i=0}^{L-1} i \cdot p(i)
$$

Dalam hal ini, $i$ adalah aras keabuan pada citra $f$ dan $p(i)$ menyatakan probabilitas kemunculan $i$ dan $\mathrm{L}$ menyatakan nilai aras keabuan tertinggi.Rumus di atas akan menghasilkan rerata kecerahan objek.

Fitur kedua berupa deviasi standar. Perhitungannya sebagai berikut:

$$
\sigma=\sqrt{\sum_{i=1}^{L-1}(i-m)^{2} p(i)}
$$

Dalam hal ini, $\sigma^{2}$ dinamakan varians atau momen orde dua ternormalisasi karena p(i) merupakan fungsi peluang. Fitur ini memberikan ukuran kekontrasan.
Fitur skewness merupakan ukuran ketidaksimetrisan terhadap rerata intensitas.Definisinya :

skewness $=\sum_{i=1}^{L-1}(i-m)^{3} p(i)(13.3)$

Skewness sering disebut sebagai momen orde tiga ternormalisasi.Nilai negatif menyatakan bahwa distribusi kecerahan condong ke kiri terhadap rerata dan nilai positif menyatakan bahwa distribusi kecerahan condong ke kanan terhadap rerata.Dalam praktik, nilai skewness dibagi dengan $(\mathrm{L}-1)^{2}$ supaya ternormalisasi.

Deskriptor energi adalah ukuran yang menyatakan distribusi intensitas piksel terhadap jangkauan aras keabuan. Definisinya sebagai berikut:

$$
\text { energi }=\sum_{i=0}^{L-1}[p(i)]^{2}(13.4)
$$

Citra yang seragam dengan satu nilai aras keabuan akan memiliki nilai energi yang maksimum, yaitu sebesar 1. Secara umum, citra dengan sedikit aras keabuan akan memiliki energi yang lebih tinggi daripada yang memiliki banyak nilai aras keabuan. Energi sering disebut sebagai keseragaman.

Entropi mengindikasikan kompleksitas citra. Perhitungannya sebagai berikut:

$$
\text { entropi }=-\sum_{i=0}^{L-1} p(i) \log _{2}(p(i))
$$

\section{(13.5)}

Semakin tinggi nilai entropi, semakin kompleks citra tersebut.Perlu diketahui, entropi dan energi ber kecenderungan berkebalikan. Entropi juga merepresentasikan jumlah informasi yang terkandung di dalam sebaran data.

Properti kehalusan biasa disertakan untuk mengukur tingkat kehalusan/kekasaran intensitas pada citra. Definisinya sebagai berikut:

$R=1-\frac{1}{1+\sigma^{2}}$

Pada rumus di atas, $\sigma$ adalah deviasi standar.Berdasarkan rumus di atas, Nilai $\mathrm{R}$ yang rendah menunjukkan bahwa citra memiliki intensitas yang kasar. Perlu 
diketahui, di dalam menghitung kehalusan, varians perlu dinormalisasi sehingga nilainya berada dalam jangkauan $\left[\begin{array}{ll}0 & 1\end{array}\right]$ dengan cara membaginya dengan $(\mathrm{L}-1)^{2}$.

\section{K-Nearest Neighbor}

K-Nearest Neighbor (KNN) adalah suatu metode yang menggunakan algoritma supervised dimana hasil dari query instance yang baru diklasifikan berdasarkan mayoritas dari kategori pada KNN. Tujuan dari algoritma ini adalah mengklasifikasikan obyek baru berdasarkan atribut dan training sample. Algoritma metode KNN sangatlah sederhana, bekerja berdasarkan jarak terpendek dari query instance ke training sample untuk menentukan KNN-nya. Training sample diproyeksikan ke ruang berdimensi banyak, dimana masingmasing dimensi merepresentasikan fitur dari data. Ruang ini dibagi menjadi bagian-bagian berdasarkan klasifikasi training sample. Sebuah titik pada ruang ini ditandai kelac $c$ jika kelas $c$ merupakan klasifikasi yang paling banyak ditemui pada $k$ buah tetangga terdekat dari titik tersebut. Dekat atau jauhnya tetangga biasanya dihitung berdasarkan Euclidean Distance yang direpresentasikan sebagai berikut :

$$
\begin{aligned}
& d=\sqrt{\left(a_{1}-b_{1}\right)^{2}+\left(a_{2}-b_{2}\right)^{2}+\cdots+\left(a_{n}-b_{n}\right)^{2}} \\
& d=\sqrt{\sum_{i=1}^{n}\left(a_{i}-b_{i}\right)^{2}}
\end{aligned}
$$

\section{Metode Penelitian}

\section{Pengumpulan Data}

Data yang digunakan dalam penelitian ini berupa citra daging ayam yang nantinya digunakan untuk data training dan data testing. Objek dari penelitian ini adalah daging ayam segar dan daging ayam berformalin dengan ukuran 1024 piksel x 1024 piksel yang disimpan dalam bentuk jpg. Proses pengambilan daging ayam berformalin dan tidak berformalin masing-masing berjumlah 50 citra sehingga didapatkan total jumlah citra daging ayam tersebut adalah 100 citra yang selanjutnya akan dibagi lagi menjadi dua yang tidak berformalin yaitu 10 buah citra untuk proses pelatihan, sedangkan selebihnya adalah 40 buah citra daging ayam mentah akan dipakai dalam proses pengujian. Pada tahap berikutnya adalah mengambil data citra daging ayam. Pengambilan data dilaku-kan dengan menggunakan camera smartphone. Untuk hari pertama diambil 50 data citra mata daging ayam, sampel daging ayam yang di-fillet dipotong-potong berukuran $\pm 4 \mathrm{~cm}$ x $3 \mathrm{~cm}$ sebanyak 50 potong dengan ketebalan $\pm 0,5 \mathrm{~mm}$. Potongan sampel tersebut ditimbang \pm $20 \mathrm{~g}$, dan dibiarkan dalam suhu ruang selama \pm 1 hari.

Proses berikutnya adalah memberikan formalin daging ayam yang dilakukan setelah pengambilan data pada hari kedua. Daging ayam yang telah dibiarkan dalam suhu ruang direndam dalam larutan formalin dengan konsentrasi $5 \%$ selama \pm 6 jam.

\section{Rancangan Sistem}

Pada subbab ini akan dijelaskan mengenai disain aplikasi dari sistem untuk implementasi metode pengolahan citra untuk melihat dagingayam yang tidak mengandung formalin dan yang mengandung formalin dari gambar atau citra. Algoritma yang digunakan dalam sistem yang akan digambar menggunakan diagram alir atau flowchart. 


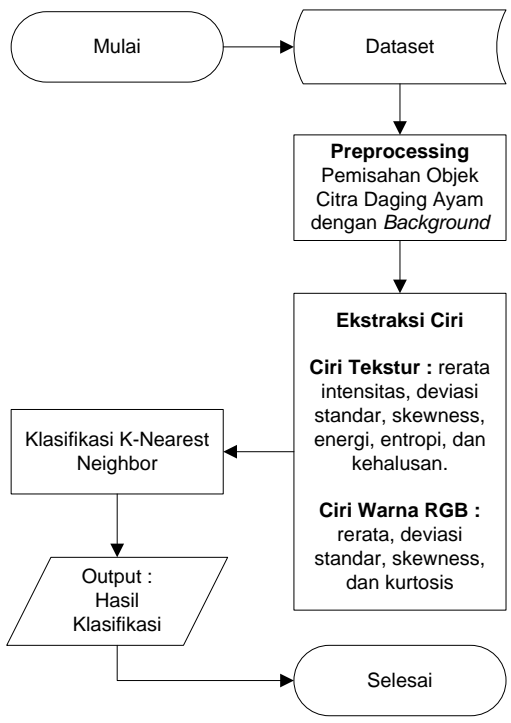

Gambar 3.1Arsitektur Sistem

\section{Hasil Penelitian}

Akurasi adalah tingkat ketepatan antara informasi yang diminta oleh pengguna dengan jawaban yang diberikan oleh sistem. Sedangkan recall adalah tingkat keberhasilan sistem dalam menemukan kembali sebuah informasi.Sedangkan di "dunia lain" seperti dunia statistika dikenal juga istilah accuray. Hasil akurasi yang diperoleh

\begin{tabular}{|l|l|l|l|}
\hline $\begin{array}{l}\text { Confution } \\
\text { matrix }\end{array}$ & $\begin{array}{l}\text { Non } \\
\text { Formalin }\end{array}$ & Formalin & \\
\hline $\begin{array}{l}\text { Prediksi } \\
\text { Non } \\
\text { Formalin }\end{array}$ & 14 & 3 & 17 \\
\hline $\begin{array}{l}\text { Prediksi } \\
\text { Formalin }\end{array}$ & 1 & 12 & 13 \\
\hline & 15 & 15 & 30 \\
\hline
\end{tabular}

Nilai Akurasinya Sebesar $=(14+12) /$ $(14+3+1+12)=26 / 30=0,8667$

Dipersentasekan $86,67 \%$

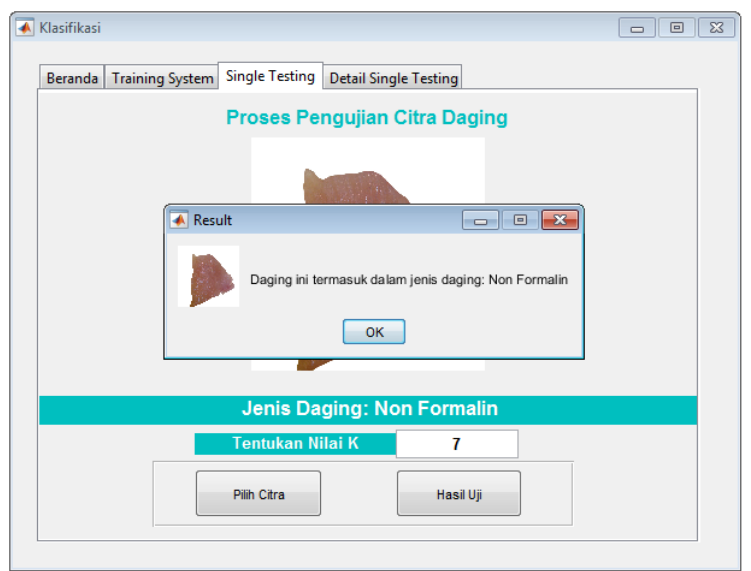

Form ini berfungsi sebagai pengujian citra data uji(testing data) citra daging ayam. Citra data uji juga ekstraksi ciri tekstur dan ciri warna yang kemudian hasil dari ekstraksi ciri warna tersebut akan dihitung jarak terdekat dengan data training yang telah ditentukan sebelumnya dengan menggunkan algoritma $k$-nearest neigbors. Pada menu ini terdapat dua tombol yakni tombol pilih citra dan Uji Hasil. Sebelum memilih citra yang akan diuji, pengguna diwajibkan mengisi nilai $\mathrm{K}$ yang akan digunakan pada proses klasifikasi algoritma $k$-nearest neighbors. Tombol pilih citra berfungsi untuk memilih citra yang akan diuji terhadap data latih. Tombol Uji Hasilberfungsi menguji data citra yang telah dipilih terhadap data latih dengan algoritmak-nearest neighbors apakah termasuk kategori formalin atau non formalin. Hasil klasifikasi akan ditampilkan dalam bentuk dialog.

\section{Kesimpulan}

Penelitian ini mengidentifikasi daging ayam berformalin dan tidak berformalin berdasarkan fitur tekstur. Metode ekstraksi fitur tekstur yang digunakan adalah Rerata Intensitas, Deviasi, Skewness, Energi, Entropi, Smoothness, MeanR, MeanG, MeanB, Devisiasi R, Devisiasi G, Devisiasi B, Skewness $R$, Skewness $G$. Hasil penelitian menunjukkan bahwa akurasi rata-rata $K$ $N N$ dalam mengidentifikasi daging ayam berformalin dan tidak berformalin sebesar $86,67 \%$. 


\section{Daftar Pustaka}

[1] Qurania, Arie. Analisis Tekstur Dan Estraksi Fitur Warna Untuk Klasifikasi Apel Berbasis Citra. Pakuan Bogor: Lokakarya Komputasi dalam sains dan teknologi Nuklir, 2012. 296-304.

[2] Whidhiasih, Retno Nugroho. Klasifikasi Buah Belimbing Berdasarkan Citra Red-Green-Blue Menggunakan KNN DAN LDA. - : Jurnal Penelitian Ilmu Komputer, 2013. 29-35.

[3] Nurhayati, Oky Dwi. Sistem Analisis Tekstur Secara Statistik Orde Pertama Untuk Mengenali Jenis Telur Ayam biasa dan telur Ayam Omega-3. - : jsiskom (Jurnal Sistem Komputer), 2015. 22523456.

[4] Asmara, Rosa Andrie. Identifikasi Kesegaran Daging Sapi berdasarkan Citranya dengan Ekstraksi Fitur Warna dan Teksturnya Menggunakan Metode Gray Level Coccurrence Matrix. Malang : SENTIA, 2017. 20852347. 